\title{
THE CORRELATION BETWEEN STUDENTS' READING MOTIVATION, VOCABULARY MASTERY AND WRITING ABILITY IN RECOUNT TEXT
}

\author{
by \\ Septika Ariyanti \\ septika.ariyanti@gmail.com \\ Aulia Hanifah Qomar \\ aulya_moetz@yahoo.com \\ PBI FKIP Universitas Muhammadiyah Metro
}

\begin{abstract}
:
The purposes of this research are to know the correlation between students' reading motivation and writing ability in recount text, the correlation between vocabulary mastery and writing ability in recount text, the correlation between students' reading motivation and vocabulary mastery and the correlation between students' reading motivation, vocabulary mastery, and writing ability in recount text. This research is quantitative research by using correlation method. In taking the sample, the researcher used saturated sampling technique. The amount of the sample are 38 students at third semester of English Study Program in Muhammadiyah University Academic Year 2015/2016. This research instrument were test and questionnaire. The finding showed that there is correlation between students' reading motivation and writing ability in recount text namely $r_{x y}=0,534$. Then, there is correlation between vocabulary mastery and writing ability in recount text namely $r_{x y}=0,583$. After that, there is correlation between students' reading motivation and vocabulary mastery namely $r_{x y}=0,488$. Lastly, there is correlation between students' reading motivation, vocabulary mastery and writing ability in recount text namely $r_{x y}=0,788$.
\end{abstract}

\section{Keyword: Correlation, Students' Reading Motivation, Vocabulary Mastery, Writing Recount Text}

Teaching English consist of four language skills such as listening, speaking, reading and writing. Writing is one productive skill besides speaking. By and large, in educational side writing activity cannot be separate from school system, because by writing the students can build their creativity. In every school, the teacher often asks student to write something based on the material given. When students are asked to write at least they need to build a 
concept. One of skill which can increase their creativity to build a writing concept is reading skill.

According to Gray and Rogers as cited in Supriyono (1998, p.12), there are five benefits of reading : 1) improve self development, 2) fulfilling the demand of intellectual, 3) fulfilling life interest, 4) to increase interest in a particular field, and 5) knowing actual matters. When people will do reading activity, they need a motivation and it is important because by having high motivation to read, one can get benefit from it and they can comprehend perfectly what they have read. Therefore, reading must be accompanied by selfmotivation.

If every single person often carry out reading activity, surely they have many vocabularies and then it can increase their list vocabularies. In addition, by having great vocabularies people can communicate to another people well. Essentially, doing communication can be done by some ways such as listening, speaking, writing and reading something. Vocabulary is needed to show people's expression in every language skill, for instance in writing. Someone's writing will be great when he or she has many vocabularies variation and it can yield the reader feel amazed to the author. Usually, in English instructional process the teacher give assignment for the students to write their own experience. Instructional material which related with experience story is recount text.

In this case, the differences of students' reading motivation, the low of vocabulary mastery, and students' difficulty in writing text especially for recount text will be a problem which is researched in this study.

Based on the data percentage of students' reading ability is in high level namely about $65,7 \%$ or about 25 students and it is more than a half of amount of students in third semester. Just a few students who get middle and low score that is 2,65\%. Then, According to the data of students' vocabulary mastery is in middle level by score $68,5-72,4$ that is $55,3 \%$ or about 21 students. This amount represents a half of students in third semester. Students who get the score is up of average value namely $28,9 \%$ or around 11 students. Lastly, Based on the data above, percentage of students' writing ability is still in middle category because the amount of students who get high score or middle score is not dominate among the other. The students who get the highest score is around 5 students or 13,15\% of students' total and who obtain the lowest score just 1 students or $2,65 \%$. 
Problem formulation in this research are:

1. Is there any correlation between students' reading motivation and writing ability in recount text?

2. Is there any correlation between vocabulary mastery and writing ability in recount?

3. Is there any correlation between students' reading motivation and vocabulary mastery?

4. Is there any correlation between students' reading motivation, vocabulary mastery, and writing ability in recount text?

\section{REVIEW OF RELATED LITERATURES}

\section{The Concept of Reading Motivation}

According to Guthrie and Wigfield as cited in Tercanlioglu (2000, p.12) who defined reading motivation as the individual's goals and beliefs regarding reading claimed that what influences reading engagement is different from what influences engagement in other fields. It must be noted that Wigfield and his associates, Reading Motivation Theory includes a general dimension that similar motivational factor such as, values, and goals also influence reading engagement. However, the main emphasis in their review is on the factors which are unique to the reading domain.

Based on the explanation related to the concept of reading and motivation, it can be said that reading motivation is individual's goals and beliefs related to reading activity. Furthermore, there are four aspect which have important role in motivating reading namely, materials, reading ability, attitude toward reading as second language and the environment.

\section{The Concept of Vocabulary Mastery}

According to Richards (2002, p.255), vocabulary is the core component of language proficiency and provides much of the basis for how well learners speak, listen, read, and write. Jackson and Amvela (2000, p.11) say that the terms of vocabulary, lexis, and lexicon are synonymous. Vocabulary is one of the language components that can affect macro skills. Some definition of vocabulary is proposed by some experts. Nunan $(1999$, p.101) states that vocabulary is a list of target language words. Furthermore, Jackson and Amvela (2000, p. 11) say that the terms vocabulary, lexis, and lexicon are synonymous. In addition, Richards and 
Schmidt (2002, p. 580) state that vocabulary is a set of lexeme, including single words, compound words, and idioms. Vocabulary is the total number of words in a language; all the words known to a person or used in a particular book, subject, etc; a list of words with their meaning, especially one that accompanies a textbook (Hornby: 1995, p. 1331).

Based on the explanation above, it can be concluded that vocabulary is the amount of words in a language and it is also main component of language proficiency in four language skills.

\section{The Concept of Writing}

Nunan (2003, p. 88) states that writing is the mental work of inventing ideas, thinking about how to express them, and organizing them into statements and paragraphs that will be clear to a reader. Another definition of writing skill is also defined by Urquhart and Mclver. Urquhart and Mclver (2005, p. 5-6) state that writing is a recursive process, which means students revise throughout the process, frequently moving back and forth among the stages. Moreover, Harmer (2004, p.31) states that writing encourages students to focus on accurate language use.

Based on all of the statements above it can be concluded that writing is a complex process to write something by presenting some ideas and it needs practice to get a good writing.

\section{The Concept of Recount Text}

Recount text is one of genre of the text which is often learnt by students in school level. There are some definitions of recount text which are conducted by some expert such Anderson as cited in Ningsih $(2014$, p.10) explain that recount is a piece of text that retells past events, usually in order in which they happened. Another definition according to Hornby (2000, p.958) says that recount is one kinds of story genre, recount tells somebody about something, that you have experienced. Besides, Hyland (2003, p.20) in his book Second Language Writing also mentioned the purpose of recount is to reconstruct past experiences by retelling events in original sequences. 
In conclusion, the writer can summarize that recount is a kind of text which retells about something happened in the past time orderly. Generally, the purpose recount text is to give information and entertain the reader itself.

\section{RESEARCH METHODOLOGY}

This research, the researcher will use quantitative method. It means that the researcher will collect and analyze the data statistically based on students' score from each variable to find out the correlation between students' reading motivation, vocabulary mastery and writing ability in recount text of $3^{\text {rd }}$ semester of English Education Study Program in Muhammadiyah University of Metro. In this research the independent variable is students' reading motivation $\left(\mathrm{X}_{1}\right)$ and vocabulary mastery $\left(\mathrm{X}_{2}\right)$. Dependent variable is writing ability in recount text $(\mathrm{Y})$. The population of this research is the third semester of English Education Study Program in Muhammadiyah University of Metro. In this research the researcher use non-probability sampling namely saturated sampling. Saturated sampling is the technique to determine sample if all of the members of population are used as sample. This mater often be done if the amount of population is relative small. the sample here are the students of $3^{\text {rd }}$ semester of English Education Study Program in Muhammadiyah University of Metro it consists of 38 students.

\section{RESEARCH FINDING AND ANALYSIS}

\section{The Result of Students' Reading Motivation $\left(\mathbf{X}_{1}\right)$}

The first instrument which is used in this research is questionnaire. The questionnaire consists of 20 statements. The highest score for each statements is 5 and the lowest score is 1 . After getting data from the questionnaire result, the researcher found that the highest score is 90 , the lowest is 44 and the average score is 67 . Based on the data frequency distribution of the resut it is obtain that from 38 students there are 3 students who got score between 44-52, 7 students got 53-61, 17 students got 62-70, 5 students got 71-78, 5 student got 79-87 and 1 student got 90 .

\section{The Result of Vocabulary Mastery $\left(\mathrm{X}_{2}\right)$}


The second instrument which is used in this research is vocabulary test. The researcher found that the highest score is 75 , the lowest is 20 and the average score is 53,1 . Based on the data frequency distribution of the resut it is obtain that from 38 students there are 2 students who got score between 20-29, 5 students got 30-39, 5 students got 40-49, 12 students got 5059, 10 student got 60-69 and 4 student got 70-79.

\section{The Result of Writing Ability in Recount Text (Y)}

The third instrument which is used in this research is writing. The highest score of this test is 100 . The score is gotten by using the scoring rubric of writing test. Scoring the writer test the researcher uses two rater. First rater is the researcher itself and the second rater is Defy Gustianing who is the student of English Study Program. After getting data from the result of writing test, the researcher found that the highest score is 83,5 , the lowest is 47,5 and the average score is 65,73 . Based on the data frequency distribution of the resut it is obtain that from 38 students there are 3 students who got score between 47-52, 6 students got 53-58, 7 students got 59-64, 11 students got 65-70, 7 students got 71-76, 2 student got 77-82 and 1 student get 83,5 .

\section{The Correlation between Students' Reading Motivation ( $\left.X_{1}\right)$ and Writing Ability in Recount Text $(\mathbf{Y})$}

From the data calculation, it is gotten $r_{x y}=0,534$. This value is consulted by $r_{\text {table(38;0,05) }}=0,320$ and the result is $0,534>0,320$, therefore there is positive correlation between $\mathrm{X}_{1}$ variable and $\mathrm{Y}$ variable. For the significant tes is gotten $t=3,791$, this value is compared with $t_{\text {table }}$ for the degree of error $5 \%$ by two tail test and $\mathrm{dk}=\mathrm{n}-2=36$, so it is

obtained $t_{\text {table }}=2.02809$. because of $\mu \neq 0$ it can be said that between $\mathrm{X}_{1}$ variable and $\mathrm{Y}$ variable has significant correlation. At the conclusion, there is any positive and significant correlation between students' reading motivation and students' writing ability in recount text. Therefore, $\mathrm{H}_{\mathrm{a}}$ is accepted. 


\section{The Correlation between Vocabulary Mastery $\left(X_{2}\right)$ and Writing Ability in Recount Text (Y)}

From the data calculation, it is gotten $r_{x y}=0,583$. This value is consulted by $r_{\text {table(38;0,05) }}=0,320$ and the result is $0,583>0,320$, therefore there is positive correlation between $\mathrm{X}_{2}$ variable and $\mathrm{Y}$ variable. For the significant tes is gotten $t=4,301$, this value is compared with $t_{\text {table }}$ for the degree of error $5 \%$ by two tail test and $\mathrm{dk}=\mathrm{n}-2=36$, so it is obtained $t_{\text {table }}=2.02809$. because of $\mu \neq 0$ it can be said that between $\mathrm{X}_{2}$ variable and $\mathrm{Y}$ variable has significant correlation. At the conclusion, there is any positive and significant correlation between vocabulary mastery and students' writing ability in recount text. Therefore, $\mathrm{H}_{\mathrm{a}}$ is accepted.

6. The Correlation between Students' Reading Motivation $\left(X_{1}\right)$ and Vocabulary Mastery $\left(\mathbf{X}_{2}\right)$

From the data calculation, it is gotten $r_{x y}=0,488$. This value is consulted by $r_{\text {table(38;0,05) }}=0,320$ and the result is $0,488>0,320$, therefore there is positive correlation between $\mathrm{X}_{1}$ variable and $\mathrm{X}_{2}$ variable. For the significant tes is gotten $t=3,839$, this value is compared with $t_{\text {table }}$ for the degree of error $5 \%$ by two tail test and $\mathrm{dk}=\mathrm{n}-2=36$, so it is obtained $t_{\text {table }}=$ 2.02809. because of $\mu \neq 0$ it can be said that between $\mathrm{X}_{1}$ variable and $\mathrm{X}_{2}$ variable has significant correlation. At the conclusion, there is any positive and significant correlation between students' reading motivation and vocabulary mastery. Therefore, $\mathrm{H}_{\mathrm{a}}$ is accepted.

\section{The Correlation between Students' Reading Motivation ( $\left.X_{1}\right)$, and Vocabulary Mastery $\left(\mathbf{X}_{2}\right)$ and Writing Ability in Recount Text (Y)}

From the data calculation, it is gotten $R_{y x 1 \times 2}=0,788$. This value is consulted by $r_{\text {table }(38 ; 0,05)}=0,320$ and the result is $0,788>0,320$, therefore there is positive correlation between $\mathrm{X}_{1}, \mathrm{X}_{2}$ and $\mathrm{Y}$ variable. For the significant tes is gotten $f_{\text {count }}=28,67$, this value is cosulted by $f_{\text {table }}$ for the degree of error $5 \%$ by dk numerator=k and dk denumerator $=(\mathrm{n}-\mathrm{k}-1)$ so it is obtained $f_{\text {table }}=3,27$ and the result is $28,67>3,27$ it can be said that between $\mathrm{X}_{1}, \mathrm{X}_{2}$ 
, and $\mathrm{Y}$ variable has significant correlation. At the conclusion, there is any positive and significant correlation between students' reading motivation, vocabulary mastery and students' writing ability in recount text. Therefore, $\mathrm{H}_{\mathrm{a}}$ is accepted.

\section{DISCUSSION}

After doing the correlation test and significant test to test the hypothesis, so the discussion of the result from this research as follows:

Based on the result of the first hypothesis there is positive and significant correlation between students' reading motivation and students' writing ability in recount text at third semester in Muhammadiyah University of Metro. This shows that the higher students' reading motivation, the better of their ability in writing recount text and vice versa. Unfortunately, not many students which get highest score in either reading motivation or writing test. Looked at data frequency distribution of students' reading motivation, just one student who gets the highest score. Besides, there are two students who get the highest score of writing test. Therefore, the students must increase their motivation to read in order to can build their writing ability.

Looked at the result of the second hypothesis there is positive and significant correlation between vocabulary and students' writing ability in recount text at third semester in Muhammadiyah University of Metro. This shows that the more students can be master of vocabulary, the better of their ability in writing recount text and vice versa. Based on the data frequency distribution of vocabulary mastery, there are some students who have not gotten good score for vocabulary mastery and it influences their writing score.

Based on the result of the third hypothesis there is positive and significant correlation between students' reading motivation and vocabulary mastery in recount text at third semester Muhammadiyah University of Metro. Although there is correlation both of the variable, the coefficient correlation shows that it has medium correlation because the result just 0,488 . It is difference from the result of first and second hypothesis which has high correlation between the variable. 
Looked at the result of the fourth hypothesis there is positive and significant correlation between students' reading motivation, vocabulary mastery and students' writing ability in recount text at third semester Muhammadiyah University of Metro. It shows that between the variable can correlate each other

\section{CONCLUSION AND SUGGESTIONS}

\section{A. Conclusion}

After the researcher finished the research and analyzed the data, the conclusion of this research is as follows :

1. There is positive and significant correlation between students' reading motivation and writing ability in recount text at third semester in Muhammadiyah University of Metro academic year 2015/2016, with coefficient correlation 0,534 and the degree of significant is 3,791

2. There is positive and significant correlation between vocabulary mastery and students' writing ability in recount text at third semester in Muhammadiyah University of Metro academic year 2015/2016, with coefficient correlation 0,583 and the degree of significant is 4,301

3. There is positive and significant correlation between students' reading motivation and vocabulary mastery at third semester in Muhammadiyah University of Metro academic year $2015 / 2016$, with coefficient correlation 0,488 and the degree of significant is 3,839

4. There is positive and significant correlation between students' reading motivation ,vocabulary mastery and students' writing ability in recount text at third semester in Muhammadiyah University of Metro academic year 2015/2016, with coefficient correlation 0,788 and the degree of significant is 28,67

\section{B. Suggestion}

After the researcher makes the conclusion of correlation between students' reading motivation ,vocabulary mastery and students' writing ability in recount text at third semester 
in Muhammadiyah University of Metro academic year 2015/2016. The researcher would give some suggestion, to the teachers or lecturers, students and for the other researchers.

\section{For Lecturers}

By knowing the result of the research, the English lecturer is hoped can give motivation to the students in order to can build their interest in reading, in mastering vocabulary and also in their writing ability. In addition, the lecturer can apply suitable strategy to develop students' capability.

\section{For the Students}

As language learner, the students must increase their reading motivation because it can influence their vocabulary mastery and writing ability. All of these aspects correlate each other, so the students are expected to apply them well and make them as one of things which can support their English well.

\section{For the Other Researchers}

This research is expected can contribute to the research education specially to find out the correlation between three variables, in this case students' reading motivation, vocabulary mastery and students' writing ability in recount text. This research is hoped to be an adequate previous study which can be used by the other researchers to conduct a further research relating to the correlation between cognitive domain and affective domain

\section{REFERENCES}

Harmer, Jeremy.(2004). How to Teach Writing.England : Pearson

Hornby, A,S.(1995). Oxford Advenced Learner's Dictionary. New York: Oxford University Press

Hyland, Ken. (2003).Second Language Writing, Cambridge : Cambridge University Presss Jackson,H and Amvela,E. (2000). Words, meaning and Vocabulary (An Introduction to Modern English

Lexicology), London : Continuum

Ningsih, Putri Aisah. (2015). The Effectiveness of Teaching Writing Recount Text by Using 
Facebook. Jakarta : Undergraduate Program UIN Syarif Hidayatullah

Nunan, D. (1999). Second Language Teaching and Learning. Boston, Massachusetts: Heinle \& Heinle

Publishers.

Richards, Jack C. (2002). Curriculum Development in Language Teaching. United Kingdom :

Cambridge University Press

Tercanlioglu,Leyla. (2001).The Nature of Turkish Students' Motivation for Reading and Its Relation to Their

Reading Frequency, The Reading Matrix.1.

Urquhart, Vicki and McIver,Monette. (2005). Teaching Writing in the Content Areas, Alexandria : Association for Supervision and Curriculum Development 